\title{
Penerapan Kedisiplinan terhadap Kinerja Karyawan PT. Sembilan Jaya Farm
}

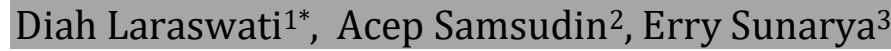

1,2,3 Universitas Muhammadiyah Sukabumi, Sukabumi - Indonesia

\section{A R T I C L E I N F O}

Article history:

Received 15 April 2020

Received in revised form 15 May 2020

Accepted 7 Jun2 2020

Available online 29 June

2020

Kata Kunci:

Kedisiplinan; Kinerja

Karyawan; Aktivitas

Karyawan

Keywords:

Discipline; Employee

Performance; Employee Activity

\begin{abstract}
A B S T R A K
Setiap perusahaan selalu menginginkan karyawannya mempunyai sikap disiplin yang baik, dengan disiplin aktivitas di dalam sebuah perusahaan dapat berjalan dengan lancar, terarah. Dan dapat lebih mudah dalam menyelesaikan pekerjaan. Kedisiplinan mencerminkan bahwa karyawan tersebut memiliki kinerja yang baik. Karena kinerja karyawan yang baik dapat dinilai jika karyawan tersebut memenuhi atau mentaati peraturanperaturan yang ditegakkan perusahaan. Riset atau penelitian ini dilakukan pada PT. Sembilan Jaya Farm Sukabumi. Adapun tujuan penelitian ini adalah untuk mengetahui seberapa besar pengaruh kedisiplinan terhadap kinerja karyawan pada PT. Sembilan Jaya Farm Sukabumi dengan populasi yang merupakan karyawan pada PT. Sembilan Jaya Farm dengan jumlah 80 responden dengan memakai teknik probability sampling dan teknik sampel jenuh. Pada penelitian ini memakai pengujian validitas dan reliabilitas. Teknik pengumpulan data yang dipakai pada data primer adalah kuisioner dan wawancara berserta data sekunder ialah studi kepustakaan. Serta teknik analisis data yang dipakai yaitu uji normalitas, uji koefisien korelasi, uji koefisien determinasi, uji regresi linear sederhana serta uji hipotesis yaitu uji t. Hasil penelitian ini menujukkan bahwa terdapat pengaruh kedisiplinan dalam mentaati peraturan akan kinerja karyawan pada PT. Sembilan Jaya Farm dengan dibuktikannya hasil pada pengujian hipotesis
\end{abstract} atau uji t menujukkan nilai thitung lebih banyak dari pada ttabel yaitu sebanyak 5.031 > 1.6646.

\begin{abstract}
A B S T R A C T
Every company always wants its employees to have a good discipline attitude, with disciplined activities within a company can run smoothly, directed. And can more easily complete the work. Discipline reflects that the employee has good performance. Because good employee performance can be assessed if the employee meets or obeys the rules that are enforced by the company. Research or research conducted at PT. Nine Jaya Farm Sukabumi. The purpose of this study was to determine how much the influence of discipline on employee performance at PT. Sembilan Jaya Farm Sukabumi with a population of employees at PT. Sembilan Jaya Farm with 80 respondents using probability sampling and saturated sample techniques. In this study using validity and reliability testing. Data collection techniques used in primary data are questionnaires and interviews along with secondary data is a literature study. And the data analysis technique used is the normality test, the correlation coefficient test, the coefficient of determination test, a simple linear regression test and a hypothesis test that is the $t$ test. The results of this study show that there is an influence of discipline in obeying the regulations on employee performance at PT. Nine Jaya Farm by proving the results of testing the hypothesis or $t$ test showed more $t$ counts than the table that is as much as 5031>1.6646
\end{abstract}

\footnotetext{
* Corresponding author.

E-mail : Diahlaraswati@ummi.ac.id (Diah Laraswati)
} 


\section{Pendahuluan}

Perkembangan pertenakan ayam di indonesia selama beberapa tahun ini semakin meningkat dan membuka peluang bisnis perkembangan ternak ayam ras dan ayam buras di indonesia adapun data terakhir yang memaparkan mengenai peningkatan pada tahun 2016 cenderung meningkat dengan populasi ayam ras mencapai 1,632 juta ekor dan peningkatan populasi ayam buras pada tahun 2016 sebesar 294 juta ekor. Peningkatan ini berdampak besar pada ilmu ternak. Perkembangan pertenakan disukabumi sudah semakin baik dengan mulai banyaknya pelaku usaha dalam bidang perternakan, namun pada kenyataannya tidak semua usha perternakan yang mampu menjalankan usahanya dengan baik salah satunya yaitu PT. Sembilan Jaya Farm.

Dari hasil wawancara yang saya lakukan pada tanggal 29 november 2019 saya mendapatkan hasil yaitu kurangnya kesadaran karyawan dalam mematuhi aturan seperti dalam memakai alat pelindung diri (APD) seperti tidak memakai masker, sarung tangan dan sepatu booth hal ini menyebabkan kesehatan pada kesehatan ayam dan juga berdampak pada hasil produksi tidak melampaui tujuan produksi. Sehingga hasil produksi mengalami kegagalaan. Untuk dapat mengetahui resiko bahaya yang ada dipertenakan pertelur atau unggas maka diperlukan suatu analisis resiko berbahaya atau disebut dengan hazards analysis, hazards analysis ditunjukan pada setiap aspek yang terdapat dipertenakan misalnya meliputi proses kerja, lingkungan kerja, kebijakan dan manajemen serta resiko-resiko kesehatan, keselamatan dan keamanan yang dialami pekerja (Suyatri and Tarsial, 2015).Oleh sebab itu penggunaan alat pelindung diri dalam bekerja sangatlah diperlukan guna menjamin keselamatan kerja dan keamanan saat bekerja.

Perusahaan yang bergerak pada bidang pertenakan sangatlah membutuhkan konsentrasi dalam bekerja karena kelengahan dalam bekerja akan berdampak buruk khususnya pertenakan ayam petelur, karyawan harus mematuhi peraturan prosedur yang diterapkan diperusahaan guna mencegah terjadinya kegagalan hasil produksi telur. Perusahaan pada bidang ternak ayam juga harus mempunyai kinerja karyawan yang memiliki kecermatan, ketelitian dan memiliki rasa tanggung jawab terhadap tugas pekerjaannya. Kinerja yang dimiliki karyawan menentukan keberhasilan perusahaan tersebut dengan memilki karyawan yang berkualitas perusahaan akan lebih mudah dalam mencapai tujuan perusahaan. Seperti yang diungkapkan Prawirosentono dalam (Shelviana, 2015) mengatakan bahwa Kinerja merupakan perolehan kerja yang telah dicapai oleh karyawan atau sekelompokan orang dalam organisasi sesuai dengan aturan dan tanggung jawab masingmasing dalam mencapai tujuan organisasi sesuai dengan aturan moral dan etika. Oleh karena itu perusahaan pertenakan harus mempunyai kinerja yang kualitas, kuantitas, terampil, memiliki rasa tanggung jawab dan disiplin mematuhi aturan yang diterapkan perusahaan.

Kedisiplinan merupakan gambaran bahwa seseorang memiliki kinerja yang baik. Dengan memiliki kedisiplinan maka tugas pekerjaan akan terselesaikan dengan tepat waktu sesuai dengan yang telah ditentukan perusahaan. menurut Hasibuan dalam (Shelviana, 2015) "Disiplin yang baik menggambarkan rasa tanggung jawab seseorang akan menyelesaikan tugas dan kewajiban yang diberikan kepadanya." Dengan ini akan mendorong semangat kerja karyawan dan akan terwujudnya tujuan perusahaan dan karyawan. Oleh karena itu, pimpinan perusahaan harus berupaya agar bawahannya tetap memiliki sikap disiplin yang baik. Seorang pemimpin dikatakan berhasil dalam memimpin bawahannya, jika bawahannya bersikap disiplin yang baik memelihara dan meningkatkan kedisiplinan yang baik merupakan suatu hal yang sulit, karena banyak faktor yang mempengaruhinya. Kedisiplinan harus ditegakkan dalam suatu organisasi atau instansi. Tanpa dukungan disiplin kerja karyawan yang baik sulit organisasi atau instansi untuk mewujudkan tujuannya yaitu pencapaian kinerja optimal karyawan. Jadi, disiplin adalah kunci keberhasilan suatu organisasi atau instansi dalam mencapai tujuannya. Untuk mengetahui lebih rinci mengenai variabel kedisiplinan dan kinerja karyawan dapat dijelaskan sebagai berikut :

Kedisiplinan, Kedisiplinan menggambarkan satu hal penting yang mesti melekat pada pribadi seseorang, Sikap disiplin akan melekat pada diri seseorang karna telah terbiasa mengikuti arahan aturan yang diterapkan dan sikap disiplin merupakan paksaan dan keharusan seseorang untuk mengikuti ketentuan yang ada. Dengan begitu sikap disiplin akan melekat pada diri seseorang. Sikap disiplin menggambarkan diri seorang tersebut memiliki sikap yang baik, memiliki rasa tanggung jawab, sikap taat terhadap aturan, sikap taat terhadap aturan waktu. Setiap perusahaan menuntut karyawannya agar memiliki kedisiplinan yang bagus, dengan karyawan yang mempunyai sikap disiplin yang bagus maka dapat mengerjakan pekerjaannya dengan lancar tanpa adanya halangan atau hambatan seperti telat dalam masuk kerja, tidak mematuhi peraturan yang telah diterapkan perusahaan, lalai dalam bekerja. Dengan karyawan yang mempunyai sikap disiplin yang bagus maka hal tersebut tentu berkurang atau jarang sekali terjadi dan bekerja lebih maksimal, dengan karyawan yang mempunyai sikap disiplin juga tentu menghasilkan kinerja yang berkompeten dan akan lebih mudah mencapai tujuan perusahaan. Kedisiplinan juga menggambarkan sikap dari diri seseorang dalam menjalankan 
aktivitas yang dapat menggambarkan sifat ketaatan dari orang tersebut,seperti mengikuti arahan yang diperintah oleh perusahaan.

Menurut (Fahmi, 2016) "kedisiplinan adalah tahap mengabdi teguh kepada aturan yang diterapkan suatu organisasi serta sanggup mendapat hukuman jika menentang aturan yang telah diterapkan dalam aturan tersebut." Adapun Menurut Hasibuan dalam (Nurlisma, 2015) "kedisiplinan merupakan kesadaran atau kesediaan seseorang untuk mentaati semua peraturan organisasi atau perusahaan dan norma-norma sosial yang berlaku."

Dari kedua pendapat diatas dapat diartikan bahwa karyawan mematuhi peraturan yang diterapkan perusahaan, selalu datang tepat waktu, selalu mengerjakan pekerjaannya dengan baik, dapat berkomitmen untuk dapat kedisiplinan pada dirinya sendiri. Disiplin merupakan ketaatan, loyal untuk mematuhi peraturan yang ditegakkan atau yang diterapkan perusahaan dan menjadi tanggung jawab seorang anggota organisasi. Disiplin perlu ditegakkan didalam sebuah organisasi dengan diterapkannya disiplin yang baik maka aktivitas pekerjaan organisasi akan berjalan dengan lancar. Tanpa adanya dorongan disiplin karyawan yang baik. Maka, perusahaan akan susah untuk membangun tujuan perusahaan. Fungsi adanya kedisiplin dalam perusahaan yaitu untuk mengatur arah kehidupan agar dapat terjalin dengan baik antar karyawan, memiliki kepribadian yang baik, disiplin dengan diikuti ancaman atau hukuman akan membuat karyawan lebih mematuhi peraturan yang ada diperusahaan.

Menurut Hasibuan (2009:195). Dalam (Meilany and Ibrahim, 2015) dimensi kedisiplinan yaitu : Tujuan dan kemampuan, Teladan Pimpinan, Balas Jasa, Keadilan, Waskat (Pengawasan melekat). Sanksi hukum, Ketegasan, Hubungan kemanusiaan.

Dalam suatu organisasi kedisiplinan sangat berpengaruh tanpa adanya unsur kedisiplinan yang baik karyawan akan tidak teratur dalam menjalankan pekerjaannya untuk itu perusahaan mengharuskan karyawan memiliki sikap disiplin. Dalam perusahaan tentunya memiliki tujuan yang jelas dan beban dialokasikan sebanding atas kemampuan karyawan. Di perusahaan tentunya memiliki pimpinan teladan pimpinan berperan untuk menjadikan contoh yang baik terhadap karyawan. Maka, pimpinan harus mempunyai sikap yang baik yang dapat dicontoh oleh bawahannya. Apresiasi atau penghargaan kepada karyawan yang memiliki sikap disiplin merupakan kecintaan terhadap karyawannya dan dapat memberikan semangat terhadap karyawan. Keadilan memotivasi karyawan agar disiplin. Sebab setiap manusia tidak ingin merasa dibeda-bedakan. Oleh sebab itu sikap seseorang pemimpin harus mencerminkan sikap keadilan dalam mengarahkan seluruh bawahannya, agar seluruh bawahannya pun mampu mempelajari sikap kedisiplinan yang diterapkan pimpinannya. Pengawasan melekat pada perusahaan merupakan langkah baik untuk mengwujudkan kedisiplinan yang baik. Dengan pengawasan pimpinan akan turun langsung mengawasi aktivitas perilaku karyawan dalam mengerjakan pekerjaannya. Dimana ada peraturan yang diterapkan maka akan ada juga sanksi yang akan diterima jika karyawan melanggar aturan yang diterapkan. Pemimpin perusahaan harus memilki sikap tegas terhadap karyawan yang tidak memilki sikap disiplin dengan memberikan sanksi hukum karyawan yang melanggar aturan. Hubungan antar karyawan juga dapat menjadikan kondisi kerja yang nyaman dan diharapkan mampu mendorong sikap disiplin pada karyawan.

Kinerja, Keberhasilan suatu perusahaan dapat diukur oleh pencapaian hasil kerja karyawan di perusahaan. Kinerja karyawan yang kompeten menggambarkan bahwa perusahaan memiliki citra yang baik serta bisa dikatakan bahwa perusahaan tersebut memilki kesuksesan dalam mendidik karyawan yang berhasil dalam menyanggupi tuntutan perusahaan dan memiiliki kemampuan yang lebih dalam bekerja. Setiap perusahaan akan menuntut karyawannya memilki kinerja yang baik dan sanggup memenuhi tugas tuntutan perusahaan dalam menyelesaikan tugas pekerjaan yang ada diperusahaan, dengan itu kinerja karyawan yang efektif dan memiliki potensi kemampuan yang cermat sangat dibutuhkan di dalam perusahaan untuk menunjang keberhasilan perusahaan itu sendiri.

Menurut (Edison, Anwar and Komariyah, 2017) mengatakan bahwa "Kinerja karyawan merupakan perolehan satu metode yang terarah sesuai dengan waktu yang telah ditentukan dan persetujuan yang telah ditetapkan."

Menurut Dharma dalam (Dwining Tyas and Swasto Sunuharyo, 2018) dimensi kinerja yaitu sebagai berikut:

1. Kualitas, yaitu berhubungan dengan baik tidaknya tingkatan yang diperoleh. Menggambarkan "rasa puas" dengan berapa lama waktu penyelesaiannya.

2. Kuantitas, yaitu hasil yang diperoleh harus tercapai, dan berhubungan dengan perhitungan dari metode pelaksanaan aktivitas dan berhubungan dengan hasil keluaran yang diperoleh.

3. Ketepatan waktu, yaitu konsisten kesepakan waktu yang telah direncanakan menentukan waktu penyelesaian suatu aktivitas. Dan merupakan jenis khusus menentukan waktu.

Kinerja karyawan yang baik yaitu kinerja karyawan yang mempunyai kualitas memiliki nilai lebih dan bisa di percaya atau dihandalkan, kinerja dapat di nilai baik apabila dapat memenuhi permintaan perusahaan 
melakukan pekerjaannya dengan baik dan memberi rasa puas terhadap perusahaan. Kinerja karyawan yang dapat dikatakan baik apabila karyawan perusahaan dapat mematuhi peraturan perusahaan seperti halnya dalam ketepatan waktu yang telah disepakati oleh karyawan dan perusahaan misalnya dalam menyelesaikan pekerjaan dengan tepat waktu. Seperti yang diungkapkan Mangkunegara dalam (Vuspasari, 2011) "kinerja adalah perolehan kerja secara kualitas, kuantitas, ketepatan waktu yng diraih oleh seorang karyawan dalam menjalankan tugas sesuai dengan tanggung jawab yang diberikan." Oleh sebab itu, karyawan harus dapat memenuhi kriteria yang diharapkan perusahaan dengan mempunyai kinerja yang efektif, handal dan berkualitas diharapkan perusahaan dapat melampaui keinginan perusahaan.

Berikut ini untuk menjelaskan lebih rinci mengenai variabel kedisiplinan, variabel kinerja karyawan dalam riset berikut ini gambar kerangka pemikiran yaitu sebagai berikut :

\begin{tabular}{|c|c|}
\hline $\begin{array}{l}\text { Kedisiplinan } \\
\text { 1.Tujuan dan } \\
\text { kemampuan } \\
\text { 2. teladan } \\
\text { pimpinan } \\
\text { 3. balas jasa } \\
\text { 4. keadilan } \\
\text { 5. pengawasan } \\
\text { melekat } \\
\text { 6. sanksi hukum } \\
\text { 7. ketegasan } \\
\text { 8. hubungan } \\
\text { manusia }\end{array}$ & $\begin{array}{c}\begin{array}{c}\text { Kinerja } \\
\text { karyawan }\end{array} \\
\text { 1. Kualiatas } \\
\text { 2. Kuantitas } \\
\text { 3. Ketepatan } \\
\begin{array}{c}\text { waktu } \\
\text { alatu }\end{array}\end{array}$ \\
\hline
\end{tabular}

Gambar 1. Kerangka pemikiran

Sumber: Hasil oleh peneliti, 2020

Berdasarkan gambar paradigma penelitian diatas maka dapt dikatakan bahwa seluruh dimensi mendukung bahwa dengan adanya kedisiplinan yang baik di perusahaan dapat berpengaruh dalam membentuk kinerja karyawan yang berkualitas. Karena dengan adanya kedisiplinan yang baik dapat mengatur semua aktivitas kerja karyawan akan lebih terarah, teratur dan dapat lebih mudah mewujudkan tujuan perusahaan.

Pengembangan Hipotesis, Hasil dari penelitian yang dipaparkan oleh (Pangarso and Intan susanti, 2016) menyatakan bahwa dengan perusahaan menekankan sikap kedisiplinan pada karyawan akan berpengaruh positif terhadap kinerja karyawan. (Hajrina and Mariam, 2016) menyatakan bahwa perusahaan memberikan apresiasi kepada karyawan yang disiplin akan mendorong kinerja karyawan yang berkualitas Dan penelitian (Nurcahya and Sary, 2018) Kedisiplinan yang tinggi akan berpengaruh akan kinerja karyawan, dengan sikap disiplin yang bagus akan memperoleh hasil kinerja yang efektif. Maka berdasarkan uraian menurut berbagai pendapat mengenai variabel kedisisplinan dan variabel kinerja karyawan maka hipotesis atau jawaban sementara pada penelitian ini terdapat pengaruh kedisiplinan akan kinerja karyawan.

\section{Metode}

Dalam penelitian ini riset penelitiian yang dipakai untuk mengukur pengaruh variabel kedisiplinan (x) dan kinerja karyawan (y) adalah Metode kuantitatif dengan asosiatif dan dengan maksud untuk mendapati pengaruh antar variabel. Teknik pengumpulan data primer menggunakan data observasi, wawancara dan kuisioner sedangkan teknik pengumpulan data sekunder menggunakan studi kepustakaan yang didukung dari buku dan jurnal-jurnal penelitian terdahulu. Populasi pada riset ini adalah pegawai PT. Sembilan Jaya Farm sampel yang ditetapkan pada eksplorasi ini sebanyak 80 informan dengan memanfaatkan teknik sampel yaitu teknik sampel jenuh yaitu seluruh personel populasi dijadikan sampel. Teknik analisis data yang dipakai dalam riset ini yaitu uji normalitas, koefisien korelasi, koefisien determinasi, analisi regresi linier sederhana dan uji t, Serta pengujian yang dilakukan untuk mengetahui keabsahan penelitian ini menggunakan uji validitas dan reabilitas. 


\section{Hasil dan pembahasan}

Jaya Farm Sukabumi, yang diolah menggunakan aplikasi IBM SPSS Statistic Version 23 didapatkan hasil yang sesuai dengan objek penelitian yang ditetapkan peneliti. Adapun hasil dan pembahasan dapat diuraikan dan dijelaskan pada tabel dibawah ini :

Tabel 1. Perolehan Uji validitas

\begin{tabular}{llll}
\hline Variabel & rhitung & rtabel & Keterangan \\
\hline X.1 & 0.425 & 0.220 & Valid \\
X.2 & 0.576 & 0.220 & Valid \\
X.3 & 0.489 & 0.220 & Valid \\
X.4 & 0.557 & 0.220 & Valid \\
X.5 & 0.297 & 0.220 & Valid \\
X.6 & 0.273 & 0.220 & Valid \\
X.7 & 0.358 & 0.220 & Valid \\
X.8 & 0.338 & 0.220 & Valid \\
Y.1 & 0.842 & 0.220 & Valid \\
Y.2 & 0.621 & 0.220 & Valid \\
Y.3 & 0.542 & 0.220 & Valid
\end{tabular}

Sumber: Hasil perhitungan penelitian, 2020

Penelitian dapat dikatakan valid jika rhitung lebih besar dari $r_{\text {tabel }}$ misalkan dengan nilai 0,425 lebih besar 0,220 maka dapat disimpulkan bahwa variabel kedisiplinan memiliki nilai valiid dan layak dilanjutkan ke tahap berikutnya. Berdasarkan hal tersebut variabel kedisiplinan bisa dikatakan diterima atau di cocok dikaitkan dengan variabel kinerja karyawan.

Tabel 2. Perolehan Uji Normalitas

\begin{tabular}{lll}
\hline \multicolumn{2}{l}{ One-Sample Kolmogorov-Smirnov Test } & \\
\hline N & & $\begin{array}{l}\text { Unstandardized } \\
\text { Residual }\end{array}$ \\
Normal Parameters ${ }^{\mathrm{a}, \mathrm{b}}$ & Mean & 80 \\
& Std. Deviation &, 0000000 \\
Most Extreme Differences & Absolute & 7,79910581 \\
& Positive &, 085 \\
Test Statistic & Negative &, 058 \\
Asymp. Sig. (2-tailed) & &,- 085 \\
$\begin{array}{l}\text { a. Test distribution is Normal. } \\
\text { b. Calculated from data. }\end{array}$ &, 085 \\
c. Lilliefors Significance Correction. &, 200 c,d \\
d. This is a lower bound of the true significance. & \\
\hline
\end{tabular}

Sumber: Hasil perhitungan peneliti, 2020

Berdasarkan keterangan diatas menunjukan bahwa nilai relevan sebesar 0,200 yang lebih besar dari 0,05. Bedasarkan hal tersebut maka dapat diketahui bahwa dalam pengambilan data mengenai variabel kedisiplinan dan kinerja karyawan dapat dikatakan bahwa penelitian ini mengambil populasi sesuai dan memang layak untuk dijadikan sebagai penelitian dengan populasi yang distribusi normal. 
Tabel 3. Perolehan analisis koefisien korelasi

\begin{tabular}{llll}
\hline Correlations & & & \\
\hline & & Kedisiplinan & kinerja karyawan \\
Kedisiplina & Pearson Correlation & 1 &, $495^{* *}$ \\
$\mathrm{n}$ & Sig. (2-tailed) & &, 000 \\
& $\mathrm{~N}$ & 80 & 80 \\
kinerja & Pearson Correlation &, $495^{* *}$ & 1 \\
karyawan & Sig. (2-tailed) &, 000 & \\
& $\mathrm{~N}$ & 80 & 80 \\
$* *$. Correlation is significant at the 0.01 level (2-tailed). & \\
\hline
\end{tabular}

Sumber: Hasil perhitungan peneliti, 2020

Hasil diatas menunjukan bahwa nilai relevan sebersar 0,000 yang berarti hasil tersebut kurang dari 0,05 yang dapat dinyatakan hubungan variabel kedisiplinan tehadap kinerja berkorelasi. Sedangkan nilai person correlation sebesar 0,495 .

Berdasarkan hasil diatas maka dapat diketahui bahwa dengan menerapkan kedisiplinan yang berkorelasi cukup kuat akan membantu suatu perusahaan khususnya PT. Sembilan Jaya Farm mampu meningkatkan kinerja karyawannya kearah yang lebih bai. Oleh sebab itu kedisiplinan pada suatu perusahaan sangat penting diterapkan dalam kegiatan perusahaan.

Tabel 4. Perolehan koefisien determinasi

\section{Model Summary}

\begin{tabular}{lllll} 
Model & $\mathrm{R}$ & R Square & Adjusted R Square & $\begin{array}{l}\text { Std. Error of the } \\
\text { Estimate }\end{array}$ \\
\hline 1 & $495^{\mathrm{a}}$ &, 245 &, 235 & 3,04521
\end{tabular}

Predictors: (Constant), kedisiplinan

Sumber: Hasil perhitungan peneliti, 2020

Perolehan diatas menetapkan bahwa nilai $\mathrm{R}$ Square sebesar 0,245 atau memiliki nilai $24,5 \%$ yang pengertiannya ditemukan pengaruh kedisiplinan akan kinerja karyawan sebesar $24,5 \%$ sedangkan sisanya $75,5 \%$ dari variabel lain. Sehingga kedisiplinan mempunyai pengaruh yang penting akan variabel kinerja karyawan.

Berdasarkan hasil koefisiensi determinasi diatas maka dapat diketahui bahwa dengan adanya kedisiplinan untuk menciptakan kinerja karyawan sangat berpengaruh dengan hasil penelitian sebesar 24,5\%. Oleh sebab itu diharapkan perusahaan dengan adanya penelitian ini dapat dijadikan sebagai acuan untuk mengembangkan kemampuan kedisiplinan dan memperhatikan penerapan kedisiplinan kepada para karyawannya untuk menciptakan kinerja perusahaan yang lebih baik lagi. 
Tabel 5. Perolehan uji regresi linier sederhana

\begin{tabular}{|c|c|c|c|}
\hline \multicolumn{4}{|c|}{ Coefficients $^{a}$} \\
\hline \multirow[b]{2}{*}{ Model } & & \multicolumn{2}{|c|}{ Unstandardized Coefficients } \\
\hline & & $\mathrm{B}$ & Std. Error \\
\hline \multirow[t]{3}{*}{1} & (Constant) & & \\
\hline & & 689 & 1,493 \\
\hline & Kedisiplinan & ,358 &, 071 \\
\hline
\end{tabular}

a. Dependent Variable: kinerja karyawan

Sumber: Hasil perhitungan peneliti, 2020

Hasil perolehan menunjukan untuk nilai regresi linier sederhana diperoleh nilai $a=0,689$ dan $b=0,358$. Selanjutnya dapat naik di persamaan regresi linier berganda sebagai berikut:

$\mathrm{Y}=\mathrm{a}+\mathrm{bx} 1$

$\mathrm{Y}=0,689+0,358 \mathrm{X} 1$ persamaan tersebut adalah:

Nilai a $=0,689$ yang artinya kedisiplinan tidak ada perselisihan atau nilainya 0 maka kinerja karyawan adalah sebesar 0,358. Koefisien regresi kedisiplinan sebanyak $b=0,358$ memberitahukan jika setiap peringkat kedisiplinan satu-satuan maka tingkat kinerja sebanyak 0,689.

Tabel 6. Perolehan uji T

\begin{tabular}{lll}
\hline Coefficients $^{\mathbf{a}}$ & & \\
\hline Standardized Coefficients & & Sig. \\
\hline Beta & $\mathrm{T}$ &, 646 \\
&, 461 & \\
\hline 495 & 5,031 &, 000 \\
\hline a. Dependent Variable: kinerja karyawan & \\
\hline
\end{tabular}

Sumber: Hasil perhitungan peneliti, 2020

Hasil perolehan menunjukan kedisiplinan memperoleh jumlah thitung sebanyak 5,031 dengan taraf relevan 0,000 dengan $\mathrm{t}$ tabel $(\mathrm{df}=\mathrm{n}-\mathrm{k}-1=80-1-1=78$ ) yang artinya t tabel sebesar 1.6646 yanhg berarti thitung lebih besar dari ttabel yaitu 5,031 >1.6646 dengan ini dapat disimpulkan bahwa terdapat hubungan kedisiplinan terhadap kinerja karyawan.

Maka dengan hasil penelitian diatas dapat dikatakan bahwa variabel kedisiplinan sangat penting diterapkan didalam suatu perusahaan khususnya pada PT. Sembilan Jaya Farm yang sedang mengalami penurunan kinerja karyawan. Kinerja karyawan tersebut dapat ditingkatkan dengan cara menerapkan kedisiplinan yang baik, dengan dibuktikannya hasil penelitian tersebut dapat membantu PT. Sembilan Jaya Farm untuk lebih menerapkan kedisiplinan pada karyawannya.

\section{Simpulan dan saran}

Berdasarkan penelitian diatas di dapatkan hasil adanya kedisiplinan terhadap kinerja karyawan pada PT. Sembilan Jaya Farm memiliki hubungan yang berkorelasi cukup kuat. Perolehan dari penelitian ini terdapat adanya hubungan secara relevan antar variabel kedisiplinan dan variabel kinerja karyawan pada PT. Sembilan Jaya Farm dengan presentase sebesar 24,5\%. selain itu terdapat hubungan kedisiplinan terhadap kinerja karyawan serta hasil uji $\mathrm{T}$ thitung lebih besar dari tabel dengan nilai 5,031>1.6646.

Bedasarkan kesimpulan diatas maka PT. Sembilan Jaya Farm perlu menerapkan kedisiplinan bagi setiap karyawannya sebab dengan memiliki sikap disiplin maka akan mengembangkan kinerja di karyawan perusahaan dan akan berakibat juga pada perolehan yang didapatkan perusahaan menjadi lebih baik. 


\section{Daftar Rujukan}

Dwining Tyas, R. and Swasto Sunuharyo, B. (2018) 'Pengaruh Disiplin Kerja Dan Lingkungan Kerja Fisik Terhadap Kinerja Karyawan', Jurnal Ilmu Manajemen (JIM), 7(2), pp. 172-180.

Edison, E., Anwar, Y. and Komariyah, I. (2017) Manajemen Sumber Daya Manusia. Bandung: Alfabeta.

Fahmi, I. (2016) Manajemen Sumber Daya Manusia Teori dan Aplikasi. Bandung: Alfa Beta.

Hajrina, R. A. and Mariam, I. (2016) 'Pengaruh Disiplin Kerja Terhadap Kinerja Karyawan Bagian Marketing Pada Hotel Millenium Sirih Jakarta', 13(2), pp. 129-136.

Meilany, P. and Ibrahim, M. (2015) 'Pengaruh Disiplin Kerja Terhadap Kinerja Karyawan PT. Indah Logistik Cabang Pekanbaru', pp. 1-11.

Nurcahya, G. A. and Sary, F. P. (2018) 'Pengaruh Disiplin Kerja Terhadap Kinerja Karyawan PT.Arah Enviromental Indonesia BAG. Surakarta', e-Proceeding of Management, 5(1), pp. 303-310.

Nurlisma (2015) 'Hubungan Antara Disiplin Kerja Dengan Kinerja Karyawan PT. Ambassador Garmindo'.

Pangarso, A. and Intan susanti, P. (2016) 'Pengaruh Disiplin Kerja Terhadap Kinerja Pegawai Di Biro Pelayanan Sosial Dasar Seketariat daerah Provinsi Jawa Barat', (2), pp. 145-160.

Shelviana, S. (2015) 'Hubungan Disiplin Kerja Dengan Kinerja Pegawai Negri Sipil (PNS) Di Kecamatan Samarinda ULU Kota Samarinda'.

Suyatri, D. and Tarsial (2015) Prinsip-Prinsip K3LH: Keselamatan Kesehatan Kerja dan Lingkungan Hidup. Malang: Gunung Samudra.

Vuspasari, K. (2011) 'Hubungan Disiplin Kerja Dengan Kinerja Karyawan Pada PT. Varia Intra Finance Cabang Lampung'. 